\title{
UM EXAME DO ESTADO DA ARTE SOBRE ENSINO RELIGIOSO NO BRASIL EM PERIÓDICOS ACADÊMICOS (2012-2017)
}

\author{
EVANDRO FRANCISCO MARQUES VARGAS ${ }^{1}$ \\ ORCID: https://orcid.org/0000-0001-5378-9904 \\ LEANDRO GARCIA PINHO \\ ORCID: https://orcid.org/0000-0002-8013-0520
}

\begin{abstract}
RESUMO: Na área da História da Educação, a temática do Ensino Religioso move debates acalorados. Este artigo toma, por questão de estudo, como vêm se delineando as produções em periódicos científicos, voltadas para a discussão do ensino religioso no Brasil, a partir de suas legislações específicas. Para tal, um levantamento foi realizado na base de dados do portal de periódicos da Coordenação de Aperfeiçoamento de Pessoal de Nível Superior; e, a partir dos artigos publicados no quinquênio 2012 a 2017, fez-se o esforço de realização de um estado da arte sobre o tema. A conclusão é que os artigos selecionados desvelam os limites e desafios à laicidade ao fazer da regulamentação do ensino religioso e sua implantação, um mecanismo de regulação da religião na esfera pública educacional. Todavia, sobressai, no resultado de nossa análise, que o processo de escolarização do ensino religioso passa por um momento ímpar na busca de afirmação curricular e reconstrução epistemológica, motivado pela positivação legal, que veda o proselitismo, e dá aporte para a discussão de temáticas e fenômenos que incorrem na realidade concreta em que se move a cultura escolar.
\end{abstract}

Palavras-chave: Ensino religioso, legislação, laicidade.

\section{AN EXAMINATION OF THE STATE OF ART IN ACADEMIC PUBLICATIONS ON RELIGIOUS EDUCATION IN BRAZIL (2012-2017)}

\begin{abstract}
In the area of the History of Education, the theme of Religious Education moves heated debates. This article takes as a matter of study how the productions in academic journals focused on the discussion of religious education in Brazil have been delineated from their specific legislations. To this end, a survey was conducted in the database of the portal of journals of the Coordination of Improvement of Higher Level Personnel and from the articles published in the five years 2012 to 2017 made the effort to achieve a state of the art on the subject. The conclusion is that the selected articles unveil the limits and challenges to secularism by making the regulation of religious teaching and its implementation a mechanism for the regulation of religion in the public educational sphere. However,
\end{abstract}

\footnotetext{
${ }^{1}$ Universidade Estadual do Norte Fluminense - Darcy Ribeiro (UENF). Campos dos Goytacazes, Rio de Janeiro (RJ), Brasil.<evandropeixxe@gmail.com>

${ }^{2}$ Universidade Estadual do Norte Fluminense - Darcy Ribeiro (UENF). Campos dos Goytacazes, Rio de Janeiro (RJ), Brasil.<leandrogarciapinho@gmaill.com>
} 
it is highlighted in the result of our analysis that the process of schooling of religious education goes through a unique moment in the search for curricular affirmation and epistemological reconstruction motivated by legal positivation, which prohibits proselytism, and gives support to the discussion of themes and phenomena that they incur the concrete reality in which the school culture moves.

Keywords: Religious education, legislation, secularism.

\section{UN EXAMEN DEL ESTADO DEL ARTE EN PUBLICACIONES ACADÉMICAS SOBRE EDUCACIÓN RELIGIOSA EN BRASIL (2012-2017)}

RESÚMEN: En el área de la Historia de la Educación, el tema de la Educación Religiosa mueve debates acalorados. Este artículo toma como cuestión de estudio cómo las producciones en revistas académicas centradas en la discusión de la educación religiosa en Brasil se han delineado a partir de sus legislaciones específicas. Con este fin, se realizó una encuesta en la base de datos del portal de revistas de la Coordinación de Mejoramiento del Personal de Nivel Superior y de los artículos publicados en los cinco años 2012 a 2017 se hizo un esfuerzo para lograr un estado del arte en el tema. La conclusión es que los artículos seleccionados revelan los límites y desafíos para el secularismo al hacer que la regulación de la enseñanza religiosa y su implementación sea un mecanismo para la regulación de la religión en la esfera educativa pública. Sin embargo, se destaca en el resultado de nuestro análisis que el proceso de escolarización de la educación religiosa atraviesa un momento único en la búsqueda de la afirmación curricular y la reconstrucción epistemológica motivada por la positividad legal, que prohíbe el proselitismo y apoya la discusión de temas. y fenómenos en los que incurren en la realidad concreta en la que se mueve la cultura escolar.

Palabras clave: Educación religiosa, legislación, laicidad.

\section{INTRODUÇÃO}

Ao contrário da longa existência que o ensino religioso tem na História da Educação brasileira, presente desde o período colonial pela ação dos jesuítas, a análise e a problematização desse tema enquanto objeto de pesquisa, ou da construção do seu processo de escolarização, são bastante recentes. Entretanto, o tema do ensino religioso tem ganhado espaço nas discussões acadêmicas, principalmente a partir da sua regulamentação na Lei de Diretrizes e Bases da Educação Nacional (LDB-EN) de 1996. A partir daquele momento, surge uma disputa em relação à laicidade do Estado brasileiro em função da manutenção deste componente disciplinar no currículo da educação básica. Esse processo é determinado por intermédio da positivação das leis (Constituição Federal de 1988, em seu artigo $\mathrm{n}^{\circ}$ 210; LDB-EN, art. 33, alterado pela Lei $\mathrm{n}^{\circ}$ 9.475, de 1997) que mobiliza a sociedade civil e política, seja em busca de sua legitimação - para assim garantir a efetivação desta positivação - seja para problematizar/denunciar e deslegitimar essa mesma positivação.

O presente artigo circunscreve essa problemática a partir de uma caracterização do estado da arte. Essa forma de recorte de pesquisa baseia-se no levantamento da literatura disponível e "requer a consulta a documentos substanciais" (THERRIEN; NÓBREGA-THERRIEN, 2004, p. 2). Segundo Ferreira (2002), o estado da arte é uma "metodologia de caráter inventariante e descritivo da produção acadêmica e científica sobre o tema que busca investigar", cujo objetivo é "mapear e discutir uma certa produção acadêmica em determinado campo do conhecimento" (FERREIRA, 2002. p.258).

O objetivo da produção deste estado da arte do ensino religioso foi discutir o posicionamento dos autores quanto à positivação e (des) positivação do ensino religioso e mapear, por meio da produção científica disponível no portal de periódicos da Coordenação de Aperfeiçoamento de Pessoal de Nível Superior (CAPES), os interesses temáticos que a comunidade científica tem utilizado para compreender este tema. 
A opção metodológica pelo portal de periódicos da CAPES para o estado da arte deu-se em função das reflexões acerca dos limites do uso de uma metodologia que é vista como descritiva e parcial (FERREIRA, 2002). Dessa forma, o presente artigo não é um estudo definitivo do tema do ensino religioso no Brasil, mas um primeiro delineamento para demarcar a literatura atualmente existente. Entretanto, há um esforço para que este seja um exercício analítico rigoroso, na medida em que resulta de um levantamento que cobre o período de 2012 a 2017.

Um aspecto particularmente relevante é que o estado da arte em questão foi orientado para analisar como vêm se delineando, a partir da LDB de 1996 e das leis específicas para o ensino religioso, as produções em periódicos científicos que estejam voltadas para a problematização da positivação e implementação do ensino religioso na escola pública brasileira.

Além disso, é importante notar dois pontos que justificam a realização de um estado da arte baseada em artigos publicados em periódicos científicos: a) do ponto de vista acadêmico e político, a relativamente recente área da Ciência da Religião no Brasil (CRE) implica um índice de publicações menor; isto é, não são muitos os periódicos dedicados a CRE no Brasil em geral e, em particular, voltados para o componente ensino religioso; e b) no próprio campo da História da Educação, existe certa lacuna no que se refere à discussão do tema ensino religioso, seja enquanto objeto de estudos, seja como fruto do processo de escolarização desse componente curricular. Por outro lado, é importante reconhecer que o limite imposto pelo escopo do método adotado, o qual se apoiou na produção de artigos científicos, não nos impede de indicar a existência de outro modo de divulgação científica bastante significativa na forma de livros. Exemplos disso são as obras de Junqueira (2015) e Junqueira; Klein; Brandenburg (2017).

\section{MATERIAL E MÉTODOS}

Um primeiro passo metodológico foi levantar a literatura em periódicos indexados no Portal de periódicos da Capes no período de 15 a 21 de maio de 2017, sendo que o descritor usado para busca foi "ensino religioso". Nessa primeira etapa, foram identificados 286 trabalhos, distinguidos pelo próprio portal em dois recursos: (a) periódicos revisados por pares (95); e (b) recursos online (163). Este último distingue quatro tipos de documento científico: artigos (143), livros (13), recursos textuais (4) e teses (3). Para fim de inclusão na base utilizada para construir o presente estado da arte, os seguintes critérios que abordassem a temática do ensino religioso foram adotados: artigos avaliados por pares; disponíveis na íntegra nas bases do portal de periódicos; idioma de publicação em português; e período de publicação compreendido entre 2012 a 2017. Já os critérios de exclusão incluíram a duplicação de publicações e a remoção dos documentos que não contemplassem os critérios de inclusão. Após a aplicação dos critérios de inclusão e exclusão, foram identificados 53 artigos. Em seguida, adotou-se outro critério de refinamento para compor este estado da arte: a presença do descritor "ensino religioso" no título, resumo ou palavras-chave, resultando na permanência de apenas 21 artigos.

Após a leitura das publicações, procedeu-se ao processo de avaliação e alocação dos estudos em quatro categorias analíticas: (1) os favoráveis à positivação do ensino religioso enquanto componente curricular na educação brasileira; (2) os desfavoráveis ou críticos à entronização do ensino religioso nas políticas educacionais; (3) os que buscassem fazer uma síntese ou reflexão metafísica entre estes dois flancos; e (4) os que não se posicionassem claramente quanto à positivação do ensino religioso na escola pública.

Em seguida, foi utilizada uma escala para a classificação da qualidade dos artigos, de acordo com o estrato WEBQUALIS 2013-2016 da plataforma sucupira. Desse ponto em diante, os trabalhos foram divididos em três níveis: a) nível 1, artigos classificados com estratos A1 e A2; b) nível 2, artigos classificados com estratos B1 e B2; e c) nível 3, artigos classificados nos estratos B3 e B4. Dada a diversidade disciplinar que o tema do ensino religioso suscita, foi feita a opção de classificar essa produção dentro da área de avaliação interdisciplinar de acordo com os diversos campos (Educação, História, Sociologia, Ciência da Religião) com os quais o objeto de estudo faz interface. 
Outro fator incluído no processo de análise foi a identificação das Instituições de Ensino Superior (IES) ou editoras que publicaram os artigos selecionados. Esses dados estão sistematizados no Quadro 1 no qual estão mapeados o título do trabalho, o ano de publicação, os autores, o nome do periódico e a Instituição de Ensino Superior - IES/editora - que publicou, a classificação no Qualis Capes e o nível de qualidade. $\mathrm{O}$ anexo apresenta um inventário dos resumos e palavras-chave dos artigos selecionados. Por fim, apresentamos uma discussão dos resultados, de forma a destacar as evidências dos estudos.

É importante destacar algumas dificuldades metodológicas encontradas, antes de passar à análise propriamente dita. A primeira dificuldade encontrada refere-se ao fato de que o Portal de Periódicos da CAPES não distingue de forma acurada as diferentes formas de produção científica (i.e., artigos científicos, capítulos de livros, dissertações ou teses). A segunda deve-se a que o filtro do Portal também não distinguiu de forma clara o recorte temporal. Quanto ao resultado da busca em periódicos avaliados por pares e após aplicação dos refinamentos - recorte temporal (2012-2017) e a presença do descritor ensino religioso no título/resumo/palavras-chave -, houve inicialmente 23 resultados. Todavia, um artigo era de período anterior (publicado em 2010) ao recorte estipulado 2012-2017, e outro se tratava de resumo de dissertação.

Quanto aos Recursos Online, ao verificar os resultados do refinamento aplicado ao tipo de recurso tese, encontram-se três resultados: duas dissertações, no Programa de Educação da Fundação Universidade de Blumenau - FURB -, defendidas nos anos 2007 e 2008; e uma tese, no Programa de Educação Escolar da Faculdade de Ciências e Letras da UNESP (Universidade Estadual Paulista). Essa tese, embora não seja sobre o tema do ensino religioso, e, sim, sobre a memória de uma escola confessional Presbiteriana de Campinas, permite um contraponto interessante, no tocante aos periódicos editados em instituições confessionais. São as instituições católicas que hegemonizam as produções sobre ensino religioso; todavia, são as IES públicas que fazem frente a essa produção. Ao aplicar a operação de refinamento da busca por recursos textuais, o resultado do portal exibiu quatro dissertações defendidas na Pontifícia Universidade Católica do Rio Grande do Sul (PUC-RS). Duas dessas dissertações continham o descritor ensino religioso no título; os outros dois resultados continham o descritor no resumo.

As dissertações com o descritor no título foram: dissertação defendida no Programa de Pós-graduação em Ciências Sociais no ano de 2007, intitulada $A$ implantação do novo modelo de ensino religioso nas escolas públicas do Estado do Rio Grande do Sul: laicidade e pluralismo religioso (RANQUETAT JÚNIOR, 2007); e a outra, defendida no programa de Teologia em 2009, intitulada Pluralismo religioso: diálogo e alteridade no ensino religioso (RECH, 2009). No caso das dissertações com o descritor no resumo, uma delas foi defendida pelo Programa de Pós-Graduação em Educação no ano de 2007 e analisa a dimensão da religiosidade humana e a prática educativa de um grupo de sete alunas do Curso Normal em atividades desenvolvidas no componente curricular de Didática do Ensino Religioso; a outra discute uma pesquisa acerca da construção de um projeto interdisciplinar no ensino médio, na qual o descritor se encontra elencado no rol das disciplinas que compunham o projeto de pesquisa.

Dentro do recorte cronológico proposto para este estado da arte, podemos realizar uma proporção entre estas produções bibliográficas $(\mathrm{n}=21)$ distribuídas anualmente (Figura 1).

Figura 1 - Distribuição anual das publicações (2012-2017)

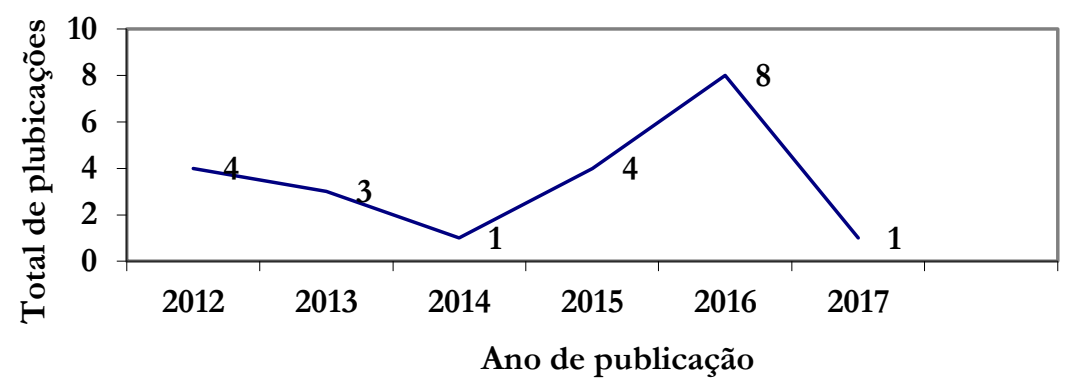


Fonte: Elaboração própria a partir do Portal de Periódicos da CAPES.

Os artigos selecionados foram agrupados em um quadro e um anexo. O quadro 1 mapeia a produção (i.e., apresenta o título, os autores e os periódicos em que os artigos foram publicados) e também divide os trabalhos em três níveis na área de avaliação interdisciplinar. Já o anexo faz um inventário da produção, destacando o resumo e as palavras-chave dos artigos selecionados. Além de apresentar os resultados desse mapeamento, o presente artigo discute e analisa os resultados do material levantado.

\section{RESULTADOS E DISCUSSÃO}

Os 21 artigos selecionados foram publicados em dez revistas científicas, de acordo com a seguinte distribuição:

a) Cinco (24,5\%) foram publicados pela revista Horizonte - Revista de Estudos de Teologia e Ciências da Religião, do Programa de Pós-graduação em Ciências da Religião, da Pontifícia Universidade Católica de Minas Gerais (PUC-MG);

b) Quatro (19,5\%) foram publicados pela revista Acta Scientiarum: Education, que é publicada trimestralmente pela Editora da Universidade Estadual de Maringá (EDUEM), focada em textos com temáticas vinculadas à educação em dois eixos: História e Filosofia da Educação e formação de professores;

c) Três (14,25\%) foram publicados pela Educação e Pesquisa, revista da Faculdade de Educação da Universidade de São Paulo (USP);

d) Dois (9,5\%) foram publicados pela Educaşão \& Sociedade, publicação do Centro de Estudos Educação e Sociedade (CEDES) ligado à Faculdade de Educação da Universidade Estadual de Campinas (UNICAMP);

e) Dois (9,5\%) foram publicados pela Revista Eventos Pedagógicos (REP's), sendo esta uma publicação da disciplina de Eventos Científicos da Metodologia de Pesquisa Educacional do Curso de Pedagogia, Faculdade de Educação e Linguagem da Universidade do Estado de Mato Grosso do Campus Universitário de Sinop (UNEMAT);

f) Um artigo (4,75\%) foi publicado pela revista Acta Scientiarum: Language and Culture, outra revista publicada pela Universidade Estadual de Maringá (UEM), mas dedicada às áreas de Letras e Linguística;

g) Um (4,75\%) foi publicado pela Interfaces da Educação, revista editada pelo Programa de Pósgraduação em Educação da Universidade Estadual de Mato Grosso do Sul (UEMS)/Unidade Universitária de Paranaíba;

h) Um $(4,75 \%)$ foi publicado pela Ciência e Educação, uma revista ligada ao Programa de PósGraduação em Educação para a Ciência, Universidade Estadual Paulista Júlio de Mesquita Filho (UNESP), Faculdade de Ciências, campus de Bauru;

i) Um $(4,75 \%)$ constitui-se da ETD - Educação Temática Digital -, publicação científica eletrônica da Faculdade de Educação da UNICAMP;

j) E, finalmente, um artigo (4,75\%) publicado pela revista Cadernos de Pesquisa da Fundação Carlos Chagas (FCC), dedicada a divulgar a produção acadêmica sobre educação, gênero e etnia.

É importante notar que, no campo da História da Educação, existem pesquisas que destacam a relevância de se pensar na circulação de saberes e modelos pedagógicos como formas de compreensão dos processos educacionais, escolarização, e formação na profissão docente (CARVALHO; PINTASSILGO, 2011; CARDOSO, 2014; ORLANDO; DANTAS; SILVA, 2015; ORLANDO; MORGADO, 2015). Todavia, quando a disciplina em questão é o Ensino Religioso, o campo da Educação é, em números gerais, aquele com mais artigos publicados, contemplando 14 dos 21 artigos selecionados, seguido pelo campo Ciências da Religião, que tem se destacado no volume de produção acadêmica, demonstrando certa proeminência no domínio neste tema. Vale lembrar que 
cinco dos artigos selecionados estão em um mesmo periódico de um programa de pós-graduação desta área. Por outro lado, é importante se ter em conta os dados sintetizados no Quadro 1, que explicita todas as variáveis utilizadas para mapear a produção aqui considerada como objeto de análise.

Quadro 1 - Mapeamento da produção em ensino religioso no portal da CAPES (2012-2017)

\begin{tabular}{|c|c|c|c|c|}
\hline & Título/Ano & Autores & $\begin{array}{l}\text { Periódico/Classificação } \\
\text { QUALIS/Editora/IES }\end{array}$ & Nível \\
\hline 1 & $\begin{array}{l}\text { Orientações legais para o ensino religioso em três estados } \\
\text { brasileiros: convergências e divergências demarcadas em } \\
\text { normativas (2017) }\end{array}$ & $\begin{array}{l}\text { LIMA, Pereira Aline; } \\
\text { MENIN, Maria } \\
\text { Suzana de Stefano. }\end{array}$ & $\begin{array}{l}\text { Acta Scientiarum: } \\
\text { Education. (UEM) } \\
\text { [B1 Interdisciplinar] }\end{array}$ & 2 \\
\hline 2 & $\begin{array}{l}\text { O veto transverso de FHC à LDB: o ensino religioso nas } \\
\text { escolas públicas (2016b) }\end{array}$ & $\begin{array}{l}\text { CUNHA, Luiz } \\
\text { Antônio. }\end{array}$ & $\begin{array}{l}\text { Educação e Pesquisa. [B1 } \\
\text { interdisciplinar] (USP) }\end{array}$ & 2 \\
\hline 3 & $\begin{array}{l}\text { Igreja, política e educação no Brasil republicano: a } \\
\text { criação do colégio D. Bosco, de Cachoeira do Campo, } \\
\text { Minas Gerais (1893-1897) (2013) }\end{array}$ & $\begin{array}{l}\text { GONÇALVES } \\
\text { NETO, Wenceslau. }\end{array}$ & $\begin{array}{l}\text { Acta Scientiarum: } \\
\text { Education. (UEM) } \\
\text { [B1 Interdisciplinar } \\
\end{array}$ & 2 \\
\hline 4 & $\begin{array}{l}\text { Ensino religioso nas escolas estaduais do Rio de Janeiro: } \\
\text { implicações para o ensino de ciências/biologia (2016) }\end{array}$ & $\begin{array}{c}\text { SELLES, Sandra } \\
\text { Escovedo; } \\
\text { DORVILLÉ Luís } \\
\text { Fernando, Marques; } \\
\text { PONTUAL, } \\
\text { Leandro Vahia. } \\
\end{array}$ & $\begin{array}{l}\text { Ciência \& Educação. [A2 } \\
\text { Interdisciplinar] (UNESP) }\end{array}$ & 1 \\
\hline 5 & $\begin{array}{l}\text { Dilema epistemológico do Ensino Religioso e formação } \\
\text { docente (2012) }\end{array}$ & $\begin{array}{l}\text { MARCOS, Wilian } \\
\text { Ramos. }\end{array}$ & $\begin{array}{l}\text { Horizonte. (PUC-MG) } \\
\text { [A2 Interdisciplinar] }\end{array}$ & 1 \\
\hline 6 & $\begin{array}{l}\text { O Ensino Religioso na escola Brasileira: alianças e } \\
\text { disputas históricas (2016) }\end{array}$ & $\begin{array}{l}\text { CECCHETTI, } \\
\text { Elcio; SANTOS, } \\
\text { Ademir Valdir dos. }\end{array}$ & $\begin{array}{l}\text { Acta Scientiarum. } \\
\text { Education. (UEM) } \\
\text { [B1 Interdisciplinar] }\end{array}$ & 2 \\
\hline 7 & $\begin{array}{l}\text { Cecília Meireles e o ensino religioso nos anos 1930: } \\
\text { embates em defesa da escola nova (2016) }\end{array}$ & $\begin{array}{l}\text { MORAES, José } \\
\text { Damiro de. }\end{array}$ & $\begin{array}{l}\text { Educação e Pesquisa. } \\
\text { [B1 Interdisciplinar] } \\
\text { (USP) }\end{array}$ & 2 \\
\hline 8 & $\begin{array}{l}\text { Um acordo insólito: ensino religioso sem ônus para os } \\
\text { poderes públicos na primeira LDB (2012) }\end{array}$ & $\begin{array}{l}\text { CUNHA, Luiz } \\
\text { Antônio; } \\
\text { FERNANDES, } \\
\text { Vânia. } \\
\end{array}$ & $\begin{array}{l}\text { Educação e Pesquisa. } \\
\text { [B1 Interdisciplinar] } \\
\text { (USP) }\end{array}$ & 2 \\
\hline 9 & $\begin{array}{l}\text { A laicidade na educação: conhecendo a história da } \\
\text { educação laica no Brasil e observando o pensamento de } \\
\text { um professor de Sinop (2015) }\end{array}$ & GIELOW, Taciane. & $\begin{array}{l}\text { Eventos Pedagógicos } \\
\text { [B4 Interdisciplinar] } \\
\text { (UNEMAT) }\end{array}$ & 3 \\
\hline 10 & Ensino Religioso: espaço dos catecismos (2014) & $\begin{array}{l}\text { JUNQUEIRA, } \\
\text { Sérgio Rogério. }\end{array}$ & $\begin{array}{l}\text { Horizonte. (PUC-MG) } \\
\text { [A2 Interdisciplinar] }\end{array}$ & 1 \\
\hline 11 & $\begin{array}{l}\text { As lendas e a imaginação simbólica: uma metodologia } \\
\text { para a sala de aula (2012) }\end{array}$ & $\begin{array}{c}\text { GOMES, Eunice } \\
\text { Simões Lins; } \\
\text { GOMES da SILVA, } \\
\text { Pierre Normando; } \\
\text { COSTA, Claudiana } \\
\text { Soares da. }\end{array}$ & $\begin{array}{l}\text { Horizonte. (PUC-MG) } \\
\text { [A2 Interdisciplinar] }\end{array}$ & 1 \\
\hline 12 & $\begin{array}{l}\text { Da "leveza" da adolescência ao "peso" de ser adulto: } \\
\text { personalidade, profissão, religião e cidadania entre alunos } \\
\text { do Ensino Médio de uma escola pública no interior do } \\
\text { estado de São Paulo (2016) }\end{array}$ & $\begin{array}{l}\text { ROIZ, Diogo da } \\
\quad \text { Silva. }\end{array}$ & $\begin{array}{l}\text { Interfaces da Educação } \\
\text { [B3 Interdisciplinar] } \\
\text { (UEMS) }\end{array}$ & 3 \\
\hline 13 & $\begin{array}{l}\text { Yalorixás e educação: Discutindo o ensino religioso nas } \\
\text { escolas (2016) }\end{array}$ & $\begin{array}{l}\text { RUSSO, Kelly; } \\
\text { ALMEIDA, } \\
\text { Alessandra. }\end{array}$ & $\begin{array}{l}\text { Cadernos de Pesquisa } \\
\text { [A2 Interdisciplinar] } \\
\text { (Fundação Carlos } \\
\text { Chagas). }\end{array}$ & 1 \\
\hline 14 & $\begin{array}{l}\text { Livros didáticos de ensino religioso: análise da } \\
\text { construção da polêmica no discurso da mídia (2012) } \\
\text { Garrido }\end{array}$ & $\begin{array}{l}\text { GARRIDO, Bruno } \\
\text { Sampaio. }\end{array}$ & $\begin{array}{l}\text { Acta Scientiarum: } \\
\text { Language and Culture. } \\
\text { [B1 Interdisciplinar] } \\
\text { (UEM) }\end{array}$ & 2 \\
\hline 15 & A influência da religião na educação escolar (2015) & LUCENA, Cidéli & Eventos Pedagógicos & 3 \\
\hline
\end{tabular}




\begin{tabular}{|c|c|c|c|c|}
\hline & & Dias. & $\begin{array}{l}\text { [B4 Interdisciplinar] } \\
\text { (UNEMAT) }\end{array}$ & \\
\hline 16 & $\begin{array}{l}\text { A entronização do ensino religioso na base nacional } \\
\text { curricular comum (2016a) }\end{array}$ & $\begin{array}{l}\text { CUNHA, Luiz } \\
\text { Antônio. }\end{array}$ & $\begin{array}{l}\text { Educação e Sociedade } \\
\text { [A2 Interdisciplinar] } \\
\text { CEDES-UNICAMP }\end{array}$ & 1 \\
\hline 17 & $\begin{array}{l}\text { Expressões religiosas em escolas públicas: representações } \\
\text { sociais ou ideologia? (2016) }\end{array}$ & $\begin{array}{l}\text { ROCHA, Maria } \\
\text { Zélia Borba. }\end{array}$ & $\begin{array}{l}\text { Acta Scientiarum: } \\
\text { Education. (UEM) } \\
\text { [B1 Interdisciplinar] }\end{array}$ & 2 \\
\hline 18 & $\begin{array}{l}\text { O Sistema Nacional de Educação e o ensino religioso } \\
\text { nas escolas públicas. (2013) }\end{array}$ & $\begin{array}{l}\text { CUNHA, Luiz } \\
\text { Antônio. }\end{array}$ & $\begin{array}{l}\text { Educação e Sociedade } \\
\text { [A2 Interdisciplinar] } \\
\text { CEDES-UNICAMP }\end{array}$ & 1 \\
\hline 19 & $\begin{array}{l}\text { Ensino religioso no estado do Rio de Janeiro: conceitos, } \\
\text { história e legislações (2015) }\end{array}$ & $\begin{array}{l}\text { PINHO, Leandro } \\
\text { Garcia; VARGAS, } \\
\text { Evandro Francisco } \\
\text { Marques. }\end{array}$ & $\begin{array}{l}\text { ETD: Educação Temática } \\
\text { Digital. } \\
\text { [B1 Interdisciplinar] } \\
\text { (UNICAMP) }\end{array}$ & 2 \\
\hline 20 & $\begin{array}{l}\text { A formação do Estado secular brasileiro: notas sobre a } \\
\text { relação entre religião, laicidade e esfera pública (2013) }\end{array}$ & $\begin{array}{l}\text { RODRIGUES, } \\
\text { Elisa. }\end{array}$ & $\begin{array}{l}\text { Horizonte. (PUC-MG) } \\
\text { [A2 Interdisciplinar] }\end{array}$ & 1 \\
\hline 21 & $\begin{array}{l}\text { Relações de gênero e orientação sexual no currículo da } \\
\text { disciplina de Ensino Religioso em escolas estaduais e } \\
\text { municipais de Recife (2015) }\end{array}$ & $\begin{array}{l}\text { OLIVEIRA, } \\
\text { Aurenéa Maria de. }\end{array}$ & $\begin{array}{l}\text { Horizonte. (PUC-MG) } \\
\text { [A2 Interdisciplinar] }\end{array}$ & 1 \\
\hline
\end{tabular}

Fonte: Elaboração própria a partir do Portal de Periódicos da CAPES.

Os artigos arrolados no Quadro 1 indicam como a questão da positivação da regulação para o ER apontada pela LBD-EN em 1996 deu novo fôlego a uma discussão que havia arrefecido desde a polemização ocorrida na década de 1930-1960 quando os pioneiros da Educação Nova, por meio do "Manifesto dos Pioneiros" de 1932, enfrentaram a hegemonia da Igreja Católica. Com aquele manifesto, os seus signatários colocaram em movimento a disputa no campo educacional por meio da ação do Estado na construção de um sistema nacional de ensino. Depois disso, em 1959, por meio do Manifesto "Mais uma vez convocados", aqueles intelectuais liberais tornaram a buscar aliados para fazer frente às investidas da Igreja Católica, que visava garantir seus interesses particularistas e confessionais na primeira Lei de Diretrizes e Bases (1961).

Finalmente, em 1996, contexto em que não mais se configura o monopólio e a hegemonia da Igreja Católica sobre a ação educativa institucionalizada, uma nova composição do campo religioso (Mariano, 2013) surge na sociedade brasileira (com a redução do contingente católico e expansão das religiões evangélicas). Essa nova conjuntura irá reativar a ação católica para garantir a retomada da positivação do ER nas escolas. Dessa vez, a estratégia é a de ocupar os espaços políticos para ventilar uma nova roupagem para a disciplina, a de cariz fenomenológico, uma vez que a Lei 9.475/97 alterou o art. 33 LDB-EN, vedando o proselitismo. Uma retomada ao viés confessional só seria lograda em 2010, nos termos do art.11 do Decreto $n^{\circ} 7107 / 2010$.

O anexo deste artigo permite observar o efeito desses marcos legais para a disputa do campo religioso em um outro enquadramento sócio-histórico. Fora daquele quadro de monopólio religioso, a disputa pela orientação da conduta dá-se nos moldes do pluralismo religioso. Essa nova condição da disputa entre o campo religioso e o político é observada pela frequência no uso dos termos laico e laicidade nos resumos e nas palavras-chave.

De um total de 95 periódicos avaliados por pares, encontrados entre 2012 e 2017, em 21 artigos foi possível examinar, de maneira mais estrita, quatro categorias de interesses temáticos sobre o ensino religioso: a) leis ou normas; b) aspectos pedagógicos; c) estudos de caso; e d) análises de controvérsias no ER. A essas temáticas se coadunam outras quatro categorias que refletem os impasses históricos, presentes nos posicionamentos dos autores: (1) os favoráveis, (2) os desfavoráveis, (3) os que propugnam uma síntese entre o ER e o campo educacional, (4) os que se abstêm de uma posição sobre a positivação do ER.

\section{Posicionamentos favoráveis à positivação do ER: a passagem do confessional ao fenomenológico}


A análise do Quadro 1 indica que, dentre os resultados bibliográficos encontrados e inventariados, seis artigos [5, 6, 9, 10, 11 e 15] apresentam argumentos com ênfase na defesa da positivação do ensino religioso (GOMES; GOMES-DA-SILVA; COSTA, 2012; MARCOS, 2012; JUNQUEIRA, 2014; LUCENA, 2015; CECHETTI; SANTOS, 2016). Nesse primeiro grupo de autores que se posicionam favoráveis à positivação, há uma discussão do problema da confessionalidade na escola pública, mas não há uma problematização que envolva um sentido negativo para esta presença no ER. O que aparece de forma clara é uma tentativa de contribuir para o fortalecimento da nova faceta fenomenológica do ER.

Pode-se citar, por exemplo, que o texto 5 remete à questão epistemológica problematizada já nos anos 2000, quando se iniciou a preocupação em desvencilhar o ER do modelo confessional. Para tanto, o texto 5 retoma a categorização dos modelos de ER - o catequético (confessional), o teológico (ecumênico) e o das Ciências da Religião (científico) -, em uma tentativa óbvia de trazer à baila uma conclusão de Pauly (2004) que propôs a secularização do ER. Todavia, é necessário frisar que o dilema epistemológico quanto ao ER não difere muito do desafio que também as Ciências Sociais encontram em face da história recente e dos desdobramentos que a industrialização, a secularização e a racionalização do mundo impuseram sobre as sociedades e sobre os indivíduos contemporâneos.

Por outro lado, no texto 6 há a preocupação evidente de percorrer as idas e vindas do ER nas legislações, na História da Educação, para estabelecer um itinerário da criação da identidade da disciplina, que, segundo seus autores, passa a ter a característica de disciplina específica e ministrada por docente especializado por ocasião do Decreto n. ${ }^{\circ}$ 2.006, de 24 de outubro de 1857 (BRASIL, 1857). Esse artigo aponta ainda que no período republicano o dilema se instaurou, visto que, por serem os conteúdos dessa disciplina moldados em conteúdos religiosos confessionais, eles não mais caberiam num país laico. A solução então encontrada persiste até hoje: oferta obrigatória da disciplina, mas com a matrícula facultativa. No entanto, o impasse continua por conta de um dilema no conceito de laicidade quanto à liberdade religiosa, que é expressa nos seguintes termos: se a laicidade exige a exclusão da confessionalidade, de um lado, ou, de outro, se invoca a continuidade dos valores morais e cristãos na escola pública. Este dilema da laicidade desdobra-se em outro problema: o ônus do Estado para com ER confessional, aprofundando a indefinição nas fronteiras entre as esferas públicas e a privadas.

Enquanto isso, o autor do texto 10 analisa o conteúdo de livros didáticos de ER no período de 1934 a 1971 e aponta para a faceta confessional na construção da identidade disciplinar que tomava o catecismo como subsídio pedagógico nesse período. A transformação que esta identidade experimentou no fim da década de 1960 e ao longo dos anos de 1970 refletiu uma guinada cultural, na medida em que a perspectiva secular assumiu contornos hegemônicos. Em função disso, o ER passou a ter uma faceta ancorada na perspectiva fenomenológica.

Já o texto 11 apresenta um relato de experiência sobre uma metodologia para professores de ER no ensino fundamental, ocorrida no ano de 2011 e aplicada a oito docentes de quatro escolas públicas municipais da cidade de João Pessoa, capital do estado da Paraíba, que se coaduna com a nova faceta fenomenológica proposta para a disciplina em uma era secular. Nessa metodologia, o estudo da mítica é apresentado como o ponto de partida para o desenvolvimento de uma imaginação simbólica para organizar as práticas religiosas.

Partindo de uma análise em microescala, o texto 15 apresenta um estudo de caso com observação participante de aulas de ER ministradas em duas turmas, uma do segundo e outra do quinto ano do ensino fundamental em uma escola pública municipal da cidade Sinop, no estado do Mato Grosso. Os resultados obtidos indicam a presença do aspecto confessional nas aulas de ER, seja pelo material didático adotado pelos professores, na metodologia baseada em aspectos de valores morais, sem aprofundamento, seja pelas práticas de oração no início das aulas. Destaca-se que a falta da formação docente específica é um fator determinante para estes resultados, uma vez que a presença dos valores religiosos atravessa a prática educacional.

\section{Posicionamentos desfavoráveis à positivação do ER: uma crítica ao confessionalismo}


A problematização em relação à presença do aspecto confessional no ER será observada no segundo grupo de autores, que se posicionam como desfavoráveis à positivação do ER. Esse grupo, composto por dez artigos $[1,2,4,7,8,9,13,16,18,19]$, apresenta críticas concretas e conceituais que deslegitimam a positivação do ER na escola pública (CUNHA; FERNANDES, 2012; CUNHA, 2013; PINHO; VARGAS, 2015; CUNHA, 2016a, 2016b; GIELON, 2015; MORAES, 2016; RUSSO; ALMEIDA, 2016; SELLES; DORVILLÉ; PONTUAL, 2016; LIMA; MENIN, 2017).

Por exemplo, as autoras do texto 1 analisam as normatizações para o ER em três estados: Rio de Janeiro, São Paulo e Paraná. Para cada um desses estados, nos termos usados em suas normatizações, há um modelo distinto para o ER: no Rio de Janeiro, é confessional; já em São Paulo, é pluriconfessional (história das religiões); no caso do Paraná, o modelo é o pluralista (interconfessional). As autoras também destacam que, independente do modelo adotado e intensidade do clericalismo presente, todos têm como radicais o termo confessional e, por isso, incorrem no proselitismo vedado pela Lei no 9.475 de 1997. Além disso, as autoras demonstram a presença de um desvio conceitual no termo laicidade, que é concebido como um dispositivo jurídico presente no texto constitucional para garantir que não haja religião oficial e para que o Estado não estabeleça vínculos com grupos religiosos, defendendo o argumento de que o Estado, por meio da positivação do ER, favorece o interesse de grupos religiosos pela acomodação da pluralidade religiosa no espaço público da escola, e não pela sua neutralidade (LIMA; MENIN, 2017).

O autor do texto 2, por seu turno, argumenta sobre a modificação do art. 33 da LDB-EN, dada pela Lei no 9.475 de 1997, chamando a atenção para a rapidez da mudança, pois, seis meses após aprovação da LDB-EN, a nova lei substituía a diretriz debatida ao longo de oito anos por um projeto substitutivo proposto por um deputado, padre, ligado à Igreja Católica. Assim, o autor dividiu os objetivos desta reforma em quatro pontos: (i) a designação do ER como parte integrante da formação do cidadão; (ii) a supressão do impedimento para o uso de recursos públicos para o ER; (iii) a delegação aos sistemas estaduais e municipais das normatizações para a seleção dos conteúdos e o magistério no ER; e (iv) a supressão das modalidades confessional e interconfessional no texto da lei. O autor do texto defende o argumento de que esses quatros pontos de modificação do artigo 33 da LDBEN estreitaram a autonomia do campo educacional no Brasil ao violar o conceito de laicidade, o que ficou evidente pelo apoio político e financiamento estatal das instituições confessionais, envolvendo o campo educacional no âmbito das disputas religiosas (CUNHA, 2016b).

Um aspecto particularmente conflituoso foi analisado pelos autores do texto 4 acerca das implicações da implementação do ER no Rio de Janeiro no ensino de Biologia. A partir do cruzamento de fontes de literatura acadêmica com os pronunciamentos de autoridades e opiniões de leitores nas mídias impressas, os autores argumentam que as implicações da presença do ensino religioso ultrapassam as contradições legais pela laicidade do Estado. Isto fica patente a partir da análise dos posicionamentos de autoridades estaduais associados a legislações que introduziram conteúdos religiosos (e.g.: Criacionismo) no conteúdo e métodos para o ensino de Ciências Biológicas, o que configura uma evidente ingerência do campo religioso no educacional.

Finalmente, o texto 9 analisa o processo de adoção dos princípios da laicidade no Brasil, articulando essa mudança social ao contexto educacional. Nesse texto, a autora analisa o posicionamento de um docente que inicialmente se resguardava afirmando ministrar o ER sem proselitismo; entretanto, em seguida, reconhece discretamente que incentiva os valores de sua própria religião. Assim, a autora conclui que um Estado laico não deve negar a religião, permitindo a manifestação de todas as suas vertentes, mas sem deixar que elas interfiram nas legislações (GIELOW, 2015).

\section{Uma síntese nos posicionamentos para a positivação do ER}

Três artigos [14, 17 e 20] procuram discutir a construção de uma síntese na polêmica (GARRIDO, 2012; RODRIGUES, 2013; ROCHA, 2017). O que se pretende nessa categoria de posicionamentos é enquadrar os autores que buscam encontrar elementos de meio termo na dualidade, favoráveis e desfavoráveis ao ER, e não somente se abster de um posicionamento. 
O texto 14 analisa as relações discursivas em segmentos da imprensa (duas reportagens e dois artigos de opinião) e sites especializados (GPER e OLE) em torno da polêmica acerca da construção dos pontos de vista apresentados sobre os livros didáticos para o ER, enquadrando-os no dilema sobre a laicidade (i.e., neutralidade versus pluralidade). $\mathrm{O}$ autor do texto destaca um constituinte semântico principal nas formações discursivas sobre essa mesma temática, aquela que envolve a questão da 'liberdade'. Os posicionamentos, embora pautados em modalizações (i.e., filtros semânticos) opostas, reivindicam esse valor; usam como estratégia a desqualificação das formações discursivas do outro grupo, abarcando essas relações interdiscursivas como geradoras da polêmica, já que um discurso precisa subjugar o outro para se sagrar vencedor.

A partir de uma pesquisa empírica, a autora do texto 17 apresenta os resultados de uma abordagem sociológica realizada em escolas do Distrito Federal entre os anos de 2010 e 2012. Os resultados do estudo constatam a presença de expressões religiosas em $60 \%$ das escolas públicas de ensino médio $(\mathrm{N}=23)$, que foram categorizadas em práticas (i.e., orações, leituras de texto sagrados), textos e imagens. A autora da pesquisa constatou que nas escolas incluídas na pesquisa não havia aula de ensino religioso, sendo que as representações criadas ou reproduzidas eram feitas pelos próprios sujeitos (i.e., professores, alunos, diretores e funcionários) e não atendiam à demanda institucional dos órgãos gestores das escolas. A autora fez então um enquadramento original, não reduzindo esses fenômenos à dicotomia legislação versus prática pedagógica; ao contrário, abarcou-os como parte dos processos de socialização na qual os diversos sujeitos assimilaram o ideário cristão e o reproduziram por sua própria iniciativa em suas práticas educativas e profissionais. Em função disso, a autora argumenta que os valores cristãos estão naturalizados em categorias universais, de tal forma que parecem invisíveis. Em outras palavras, a coerção deixou de ser externa para se tornar interna e corporificada na mentalidade individual de sujeitos livres.

\section{Os que não se posicionam quanto à positivação do ER}

Nos três artigos restantes (3, 12 e 21), os autores não se posicionam claramente acerca da (não) positivação do ER e enfatizam outras temáticas, tais como a questão de gênero e os relatos de experiência (GONÇALVES NETO, 2013; OLIVEIRA, 2015; ROIZ 2016).

No texto 21, a autora faz uma pesquisa sobre a relação de gêneros no currículo do ER no estado de Pernambuco em quatro escolas (duas estaduais e duas municipais) entre os anos 2013 e 2014. No tocante ao aspecto legal para o ER, a autora lembra que o texto infraconstitucional para a disciplina no estado determina o não proselitismo. Já no processo de análise, a autora identifica uma modulação híbrida para o magistério do ER que mistura "elementos de catequese e leituras mais contemporâneas de compreensão da disciplina" (OLIVEIRA, 2015, p. 1514). Os resultados do estudo trazem ao menos um dado instigante: o reconhecimento majoritário, nos sujeitos da pesquisa, de que o ER tem o sentido de valorizar a diversidade religiosa e sem proselitismos. O mesmo sentido de coesão não ocorre quando esses sentidos e significados se entrecruzam com as temáticas de gênero/sexualidade, reiterando, em sua maioria, um lugar de submissão e opressão para as mulheres e, sobretudo, as com orientação sexual marginalizada.

O texto 12 aborda uma experiência de um trabalho interdisciplinar realizado em 2004 com as disciplinas de História, Ensino Religioso e Filosofia em uma escola estadual na cidade de Santa Fé do Sul (SP). O foco dessa experiência foi a preparação de alunos que estivessem na fase final do Ensino Fundamental II e nos dois primeiros anos do Ensino Médio para o exercício da cidadania, a escolha profissional e para a reflexão do mundo em que vivem. $\mathrm{O}$ autor do texto não aborda a questão legal do ER, e o argumento quanto a esta temática se encontra na relevância de trabalhos integrados na escola e seus desdobramentos no amadurecimento da personalidade dos alunos, constituindo fundamentos para as escolhas religiosas e profissionais que favoreceriam o exercício da cidadania.

A Figura 2 apresenta o balanço dessas categorizações, apresentando o quantitativo referente à nossa interpretação acerca do posicionamento dos autores quanto ao ER.

Figura 2 - Posição dos autores quanto ao ER 


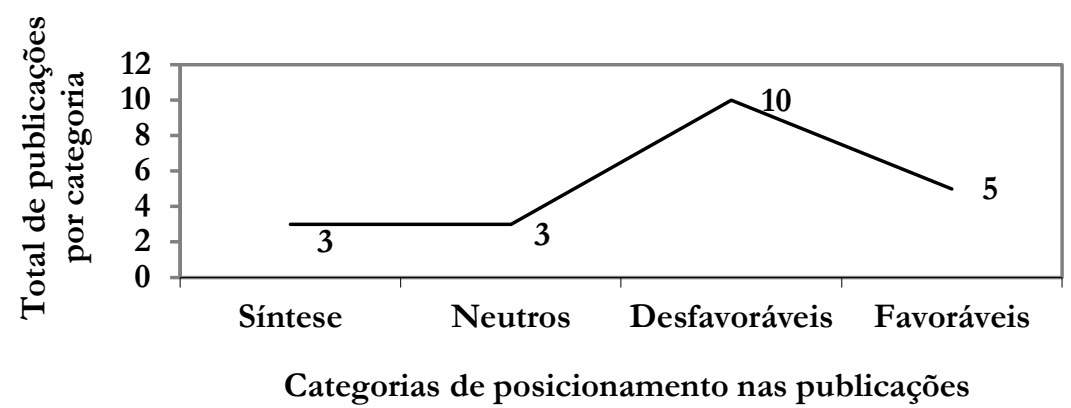

Fonte: Elaboração própria a partir do Portal de Periódicos da CAPES.

Em relação ao total de autores $(n=27)$, cabe destacar que seis artigos foram escritos em coautoria; quatro artigos com dois autores, e dois artigos com três autores. $\mathrm{O}$ autor que se destaca na liderança das discussões é Luiz Antônio Cunha (2012, 2013, 2016a e 2016b), com quatro trabalhos publicados, sendo um em coautoria. Os demais autores têm, cada um, uma única produção.

Em relação às temáticas abordadas, as mesmas foram divididas em quatro categorias: a) leis ou normas com sete artigos $[1,2,6,8,16,18,19]$; b) aspectos pedagógicos com nove artigos [3, 4, 5, 7, $10,11,13,15,21]$; c) estudos de caso, com dois artigos [1,12]; e d) análises de controvérsias no ER, com três artigos $[14,17,20]$.

No tocante aos níveis de qualidade dos artigos, foi determinado que nove deles estavam enquadrados no nível 1 (43\%); outros nove no nível 2 (43\%); e três artigos no nível 3 (14\%). Assim, a maioria das publicações $(n=18)$ está classificada entre os níveis de qualidade 1 e 2 . Este resultado aponta relevância do tema para o segmento da comunidade científica que debate a questão do ER. Além disso, é importante notar que o período científico que concentra maior parte das publicações $(24,5 \%)$ é publicado por uma instituição confessional (PUC-MG). Tal resultado parece evidenciar a imbricação entre Estado e Religião, que resulta na tensão entre público e privado na sociedade brasileira, marcada pelo caráter patrimonialista de sua fundação. Nesse sentido, Faoro aponta que:

O patrimonialismo, organização política básica, fecha-se sobre si próprio com o estamento, de caráter marcadamente burocrático. Burocracia não no sentido moderno, como aparelhamento racional, mas da apropriação do cargo - o cargo carregado de poder próprio, articulado com o príncipe, sem a anulação da esfera própria de competência (FAORO, 2001, p.101).

A relação entre Estado e Religião, nos primeiros momentos da formação social brasileira, é marcada pela presença do regime de padroado que, segundo relato de Américo Jacobina Lacombe, consistiu

[...] praticamente no controle das nomeações das autoridades eclesiásticas pelo Estado e na direção, por parte deste, das finanças da Igreja. Mas, na verdade, de tal maneira estava a administração eclesiástica entrosada na máquina administrativa do governo civil, que seria difícil ao vulgo ver nela não um departamento do Estado, mas um poder autônomo (FAORO, 2001, p. 235-236).

Em relação à importância do patrimonialismo, o autor do texto 3, ao discutir a memória de uma instituição de ensino confessional, apresentou elementos de imbricação entre Estado e Instituições de ensino confessionais que decorrem da influência deste elemento no estado de Minas Gerais no período de transição do século XIX para o XX. Assim, Gonçalves Neto (2013) afirmou que:

A reação antiliberal (ultramontana) da Igreja contará no Brasil com o auxílio de congregações religiosas para ação evangélica e educacional, sendo analisada aqui iniciativa dos Salesianos na edificação de uma escola profissionalizante em Cachoeira do Campo, distrito de Ouro Preto MG. Destacam-se as intensas relações de caráter político entre religiosos e poderes públicos no âmbito regional e local (GONÇALVES NETO, 2013, p. 49). 
Esse patrimonialismo religioso, herança do regime de padroado, manifestaria a continuidade dessa tradição, visto que, já no período republicano, conforme destaca Gonçalves Neto (2013), em 1893 houve subvenção estatal para a construção de um colégio salesiano. Contudo, a relação de patrimonialismo entre Igreja e Estado não era mais consensual. Esse juízo crítico vinha boa parte da tradição secular, que se constitui em um corpus no movimento cultural do Iluminismo. "O respeito devotado ao padre e ao clero, a obediência aos padrões religiosos, não impediram que a supremacia civil mantivesse suas prerrogativas de comando, alicerçadas numa secular luta" (FAORO, 2001, p. 236). Isso pode ser notado na atitude do Marquês de Pombal em laicizar o ensino com a expulsão dos jesuítas.

Nos artigos analisados, a discussão do patrimonialismo não resvala nessa baliza teórica de Faoro (2001), para quem os jesuítas, em maior medida, e as outras ordens, secundariamente, conseguiram conservar uma moldura religiosa para o País. É importante notar que tais impasses em torno do público versus privado estão presentes nos artigos 3 de Gonçalves Neto (2013) e, mais diretamente, no artigo 5 de Marcos (2012) e no artigo 20 de Rodrigues (2013).

\section{O peso do passado e perspectivas atuais para o ER}

Rodrigues (2013) chega a usar o termo "patrimonial", mas o faz somando-o ao termo "tradicional" quando aborda a relação pública e privada entre Igreja e Estado. Além disso, a autora utiliza-se do viés da construção de uma nova reflexão teórica na questão da laicidade com a secularização, que passam a seguir "em direção à lógica burocrática e moderna (própria dos Estados de direito), na qual o indivíduo toma para si a responsabilidade de significar suas ações, o que antes ficava a cargo do discurso religioso" (RODRIGUES, 2013, p. 154).

Pode-se vislumbrar que até os presentes dias a tensão do campo religioso sobre o campo político educacional se faz presente em uma interface entre as esferas seculares e religiosas, conforme constatado na promulgação do acordo Brasil-Santa Sé, como ficou conhecido o Decreto no 7.107/2010 - uma marca profunda deixada pela herança colonial para a História da Educação brasileira que pode ser enquadrada enquanto manifestação de um peculiar 'patrimonialismo religioso' no campo educacional.

Mas, contraditoriamente, em algumas proposições e estudos no campo da(s) Ciência(s) da(s) Religião(ões), tem-se combatido o caráter confessional que o componente curricular do ensino religioso ainda apresenta sobre fenômenos religiosos, os mais diversos, no cotidiano das escolas.

O fato notório é que, pelo menos no âmbito da(s) Ciência(s) da(s) Religião(ões), o interesse pelo ensino religioso tem-se constituído à medida que a própria área no Brasil se consolida e define suas especialidades enquanto área de saber. Entretanto, há que se observar que esse processo é bastante recente e tem relação com a discussão da Aplicação da(s) Ciência(s) da(s) Religião(ões).

A escolarização do ensino religioso passa por um momento ímpar na busca de afirmação curricular e reconstrução epistemológica motivada pela positivação legal, que veda o proselitismo e dá o aporte para as discussões de temáticas e fenômenos atuais que ocorrem na realidade concreta em que se move a cultura escolar. Esta proposição envolve pesquisas e formulações teóricas que buscam um fundamento epistemológico para alicerçar o estatuto disciplinar para o ER em um campo de conhecimento científico.

A homologação das Diretrizes Curriculares Nacionais por Resolução CNE/CP 5/2018 para a formação docente nesta disciplina em dezembro de 2018 é um marco relevante no sentido da profissionalização desses docentes. Com essa DCN, a licenciatura em CRE "constitui-se como habilitação em nível de formação inicial para o exercício da docência do Ensino Religioso na Educação Básica” (BRASIL, 2018, p. 64), em um movimento inédito em relação ao patrimonialismo religioso na História da Educação brasileira. 


\section{CONSIDERAÇÕES FINAIS}

O presente artigo apresenta o estado da arte das temáticas recorrentes e as posições dos autores quanto à positivação do ER que ressoam dos impasses históricos presentes na História da Educação quanto à laicidade do Estado, bem como a identificação de uma série de posições distintas acerca do tema. No flanco dos que defendem a positivação, existem desde reflexões epistemológicas que buscam legitimar cientificamente o campo da(s) ciência(s) da(s) religião(ões) por meio de pesquisas com preocupações teóricas na questão do currículo, material didático, formação docente, como por meio das habilidades e competências para o exercício da docência, na construção de uma identidade profissional e mesmo na profissionalização docente; enfim, apostam na legitimidade jurídica e pedagógica da disciplina. Por outro lado, uma segunda vertente inclui aqueles que apregoam sua não positivação, com pesquisas que mostram os resultados negativos da relação entre Estado/religião/educação, no tocante à discriminação e práticas de intolerância/racismo, violações de direitos humanos. Nesses grupos, a construção teórica sustenta-se por meio do rigor dos paradigmas consolidados em disciplinas especializadas, principalmente da sociologia, ressoando em eventos acadêmicos da sociedade civil organizada.

A análise da literatura recolhida identificou nuances entre esses diferentes flancos e os impactos dos mesmos na configuração de um campo em disputa, seja na apropriação das concepções existentes pelas legislações estaduais para a formação/habilitação docente, seja pela utilização de seus conteúdos para a composição de materiais didáticos e de cursos de licenciaturas em instituições de ensino superior ofertantes de licenciatura em CRE. Além disso, salienta-se como um de seus desdobramentos a publicação das DCN para a formação profissional do docente atrelado mais ao campo educacional do que ao eclesial. Um elemento saliente nesse processo de análise foi a constatação de que houve um fortalecimento da perspectiva da laicidade na Educação. À maneira de uma exceção à regra, este documento pode ser configurado como um ato político de contraposição ao julgamento da Ação Direta de Inconstitucionalidade (ADI) sobre o Ensino Religioso no Supremo Tribunal Federal (STF), que, em setembro de 2017, julgou - por 6 a 5 - a improcedência da ADI, mantendo a legalidade do ER Confessional.

Isso se dá em meio a uma tensão que envolve a visão de mundo dos sujeitos, conforme foi identificado no posicionamento dos autores estudados. A ideia aqui foi contribuir com uma possível elaboração sintética que evidencie essa contradição ou, pelo menos, ajude na reflexão sobre esse processo ao propor o debate de elementos que auxiliem na identificação de critérios avaliativos para essa questão. Cabe destacar que, para se alcançar um saber integral, é preciso que o indivíduo articule e sistematize as diversas formas de conhecimento. Essa opção adequa-se melhor no contexto multicultural que a complexidade social nos condiciona. De outro modo, ser plural não significa necessariamente ser diversionista. A sociedade tem na sua composição a interação entre diferentes campos: mítico/religioso, científico, senso comum, filosófico, artístico.

Esses movimentos, sob uma espécie de pêndulo, arregimentam posições que ressoam dos impasses históricos presentes na relação do Ensino Religioso com a laicidade do Estado. Assim sendo, se, de um lado do movimento desse pêndulo, a produção científica expressa um tipo de anomia na regulação dessa política educacional, no sentido oposto desse movimento há um direcionamento para um tipo de autonomia pedagógica, ancorada em uma produção intelectual que se constitui para fazer frente à heteronomia do campo religioso. Entretanto, a força que impulsiona o movimento incessante desse pêndulo advém de uma ideia comum, que é a liberdade de ensino, a qual não deveria ser posta em xeque.

\section{REFERÊNCIAS}

BRASIL. Conselho Nacional de Educação. Resolução CP/CNE $\mathbf{n}^{\mathbf{0}} \mathbf{0 5}$ /2018. Institui as Diretrizes Curriculares Nacionais para o curso de licenciatura em Ciências da Religião e dá outras providências. Brasília, DF: Ministério da Educação, 2018. Disponível em: http://portal.mec.gov.br/docman/janeiro2019-pdf/105531-rcp005-18/file. Acesso em: 05 nov. 2019. 
BRASIL. [Constituição (1988)]. Constituição da República Federativa do Brasil. Brasília, DF: Senado Federal, 1988. Disponível em:

http://www.planalto.gov.br/ccivil_03/constituicao/constituicaocompilado.htm. Acesso em: 22 jan. 2019.

BRASIL. Decreto n. ${ }^{\circ}$ 2.006, de 24 de outubro de 1857. Approva o Regulamento para os collegios publicos de instrucção secundaria do Municipio da Côrte. In Coleção de Leis do Império do Brasil. 1857. Disponível em: http://www2.camara.leg.br/legin/fed/decret/1824- 1899/decreto-2006-24outubro-1857-558097- publicacaooriginal-78997-pe.html. Acesso em: 04 nov. 2019.

BRASIL. Lei $\mathrm{n}^{\circ} \mathbf{9 . 3 9 4 / 9 6}$, de 20 de dezembro de 1996. Estabelece as diretrizes e bases da educação nacional. Brasília, DF. Disponível em: http://www.planalto.gov.br/ccivil_03/LEIS/L9394.htm. Acesso em: 22 jan. 2019.

BRASIL. Lei $\mathbf{n}^{\circ} \mathbf{9 . 4 7 5}$, de 22 de julho de 1997. Dá nova redação ao art. 33 da Lei nº 9.394, de 20 de dezembro de 1996, que estabelece as diretrizes e bases da educação nacional. DF. Disponível em: https://www2.camara.leg.br/legin/fed/lei/1997/lei-9475-22-julho-1997-365391-publicacaooriginal-1pl.html. Acesso em: 14 nov. 2020.

CARDOSO, T. F. L. (Org.). História da Profissão docente no Brasil e em Portugal. Rio de Janeiro: Mauad X/FAPERJ, 2014.

CARVALHO, M. M. C.; PINTASSILGO, J. Modelos Culturais saberes pedagógicos, instituições educacionais. São Paulo: Editora da Universidade de São Paulo/FAPESP, 2011.

CECCHETTI, E; SANTOS, A. V. O Ensino Religioso na escola brasileira: alianças e disputas históricas. Acta Scientiarum. Education, Maringá, n. 2, p. 131-141, abr./mai./jun. 2016.

CUNHA, L. A. A entronização do ensino religioso na base nacional curricular comum. Educação \& Sociedade, São Paulo, n. 134, p. 266-284, jan./fev./mar. $2016 a$.

CUNHA, L. A. O Sistema Nacional de Educação e o ensino religioso nas escolas públicas. Educação \& Sociedade, Campinas, n. 124, p. 925-941, jul./ago./set. 2013.

CUNHA, L. A. O veto transverso de FHC à LDB: o ensino religioso nas escolas públicas. Educação e Pesquisa, São Paulo, n. 3, p. 681-696, jul./ago./set. 2016b.

CUNHA, L. A.; FERNANDES, V. Um acordo insólito: ensino religioso sem ônus para os poderes públicos na primeira LDB. Educação e Pesquisa, São Paulo, n. 4, p. 849-864, out./nov./dez. 2012.

SELLES, S. E.; DORVILLÉ, L. F. M.; PONTUAL, L. V. Ensino religioso nas escolas estaduais do Rio de Janeiro: implicações para o ensino de ciências/biologia. Ciência \& Educação, Bauru, n. 4, p. 875894, out./nov./dez. 2016.

FAORO, R. Os donos do poder: formação do patronato político brasileiro. 3. ed. rev. São Paulo: Globo, 2001.

FERREIRA, N. S. de A. As pesquisas denominadas "estado da arte". Revista Educação \& Sociedade, Campinas, n. 79, p. 257-272, ago. 2002. 
GARRIDO, B. S. Livros didáticos de ensino religioso: análise da construção da polêmica no discurso da mídia. Acta Scientiarum. Language and Culture, Maringá, n. 2, p. 207-215, jul./ago./set./out./nov./dez. 2012.

GIELOW, T. C. A laicidade na educação: conhecendo a história da educação laica no Brasil e observando o pensamento de um professor de Sinop. Eventos Pedagógicos, n. 4, p. 283-293, nov./dez. 2015.

GOMES, E. S. L.; GOMES-DA-SILVA, P. N.; COSTA, C. S. As lendas e a imaginação simbólica: uma metodologia para a sala de aula. Horizonte, Belo Horizonte, n. 26, p.538-551, abr./mai./jun. 2012.

GONÇALVES NETO, W. Igreja, política e educação no Brasil republicano: a criação do colégio D. Bosco, de Cachoeira do Campo, Minas Gerais (1893-1897). Acta Scientiarum. Education, Maringá, n. 1, p. 49-55, jan./fev./mar./abr./mai./jun. 2013.

JUNQUEIRA, S. R. A. Ensino Religioso: espaço dos catecismos. Horizonte, Belo Horizonte, n. 36, p. 1283-1314, out./dez. 2014.

JUNQUEIRA, S. R. A.; KLEIN, R; BRANDENBURG, L. E.; Compêndio do Ensino Religioso. São Leopoldo: Sinodal, 2017.

JUNQUEIRA, S. R. A. (org.). Ensino Religioso no Brasil. São Leopoldo: Insular, 2015.

LIMA, A. P.; MENIN, M. S. de S. Orientações legais para o ensino religioso em três estados brasileiros: convergências e divergências demarcadas em normativas. Acta Scientiarum. Education, Maringá, n. 2, p. 141-152, abr./mai./jun. 2017.

LUCENA, C. D. A influência da religião na educação escolar. Eventos Pedagógicos, Sinop, n. 4, p. 55-65, nov./dez. 2015.

MARCOS, W. R. Dilema epistemológico do Ensino Religioso e formação docente. Horizonte, Belo Horizonte, n. 28, p. 1435-1457, out./nov./dez. 2012.

MARIANO, R. Mudanças no campo religioso brasileiro no Censo 2010. Debates do NER, Porto Alegre, v. 2, n. 24, p. 119-137, jul./dez. 2013.

MORAES, J. D. Cecília Meireles e o ensino religioso nos anos 1930: embates em defesa da escola nova. Educação e Pesquisa, n. 3, p. 741-754, jul./ago./set. 2016.

OLIVEIRA, A. M. Relações de gênero e orientação sexual no currículo da disciplina de Ensino Religioso em escolas estaduais e municipais de Recife. Horizonte, Belo Horizonte, n. 39, p. 1510-1533, jul./ago./set. 2015.

ORLANDO, E. A.; DANTAS, M. J.; SILVA, A. L. (Org.). Mulheres em trânsito: intercâmbios, formação docente, circulação de saberes e práticas pedagógicas. Curitiba: CRV, 2015, p. 81-107.

ORLANDO, E. A.; MOGARRO, J. M. Estratégias católicas de formação de professores e circulação de modelos culturais e pedagógicos no Brasil e em Portugal. Rev. Diálogo Educacional, Curitiba, v. 15, n. 46, p. 749-769, set./dez. 2015.

PAULY, E. L. O dilema epistemológico do ensino religioso. Rev. Bras. Educ., Rio de Janeiro, n. 27, p. 172-182, dez. 2004. 
PINHO, L. G.; VARGAS, E. F. M. Ensino religioso no estado do Rio de Janeiro: conceitos, história e legislações. Educação Temática Digital, Campinas, n. 2, p. 308-327, mai./jun./jul./ago. 2015.

RANQUETAT JÚNIOR, C. A. A implantação do novo modelo de ensino religioso nas escolas públicas do Estado do Rio Grande do Sul: laicidade e pluralismo religioso. 2007. Dissertação (Mestrado em Ciências Sociais) - Faculdade de Filosofia e Ciências Humanas, Pontifícia Universidade Católica do Rio Grande do Sul, Rio Grande do Sul, 2007.

RECH, V. T. Pluralismo religioso: diálogo e alteridade no ensino religioso. 2009. Dissertação (Mestrado em Teologia) - Faculdade de Teologia, Pontifícia Universidade Católica do Rio Grande do Sul, Rio Grande do Sul, 2009.

ROCHA, M. Z. B. Expressões religiosas em escolas públicas: representações sociais ou ideologia? Acta Scientiarum. Education, Maringá, n. 3, p. 231-246, jul./ago./set. 2016.

RODRIGUES, E. A formação do Estado secular brasileiro: notas sobre a relação entre religião, laicidade e esfera pública. Horizonte, Belo Horizonte, n. 29, p. 149-174, jan./fev./mar. 2013.

ROIZ, D. da S. Da "leveza" da adolescência ao "peso" de ser adulto: personalidade, profissão, religião e cidadania entre alunos do Ensino Médio de uma escola pública no interior do estado de São Paulo. Interfaces da Educação, Paranaíba, n. 20, p. 41-64, mai./jun./jul./ago. 2016.

RUSSO, K.; ALMEIDA, A. Yalorixás e educação: discutindo o ensino religioso nas escolas. Cadernos de Pesquisa, São Paulo, n. 160, p. 466-483, abr./mai./jun. 2016.

THERRIEN, J.; NÓBREGA-THERRIEN, S. M. Os trabalhos científicos e o estado da questão: reflexões teórico-metodológicas. Estudos em avaliação educacional, São Paulo, n. 30, p. 05-16, jul./ago./set./out./nov./dez. 2004. 
ANEXO 1 - Inventário dos resumos e palavras-chave nos artigos selecionados

\begin{tabular}{|c|c|c|}
\hline & Resumo & Palavras-chave \\
\hline 1 & $\begin{array}{l}\text { O artigo oferece um panorama do que tem sido, do ponto de vista normativo, o Ensino } \\
\text { Religioso em três estados brasileiros que regulamentaram sua oferta de maneira distinta. } \\
\text { Numa perspectiva qualitativa de pesquisa, promove-se uma análise cuja atenção voltou- } \\
\text { se à estrutura e às regras formais da disciplina e a observou a partir das conexões e } \\
\text { orientações formais-legais. De modo a considerar as elaborações apresentadas, } \\
\text { evidencia-se que, embora haja um aparente distanciamento de modelos de ensino, suas } \\
\text { justificativas se assemelham, fazendo com que, independentemente do modelo adotado, } \\
\text { o ER seja um espaço em que o objetivo maior seja o que se considera, genericamente, } \\
\text { como a formação integral do sujeito. Vista dessa forma, postula-se que a disciplina pode } \\
\text { acabar tensionando os limites da laicidade e desfavorecer indivíduos que não professam } \\
\text { nenhuma religião. }\end{array}$ & $\begin{array}{l}\text { Ensino Religioso, } \\
\text { Laicidade, } \\
\text { Currículos. }\end{array}$ \\
\hline 2 & $\begin{array}{l}\text { Este artigo analisa o processo de reforma da Lei de Diretrizes e Bases da Educação } \\
\text { Nacional-LDB (9.394/1996), pela Lei } 9.475 / 1997 \text {, acerca do ensino religioso nas } \\
\text { escolas públicas. Essa reforma foi desencadeada pelo veto transverso do presidente } \\
\text { Fernando Henrique Cardoso, ao convidar o Congresso Nacional a proceder as } \\
\text { mudanças na LDB, conforme as demandas da Conferência Nacional dos Bispos } \\
\text { (Católicos) do Brasil. A principal fonte das informações foram o Diário da Câmara dos } \\
\text { Deputados e o Diário do Senado Federal. Os argumentos de deputados e senadores a } \\
\text { respeito dos temas em discussão foram postos em confronto, de modo a desenhar um } \\
\text { panorama em que os defensores das demandas da Igreja Católica assumiram posição } \\
\text { hegemônica. A principal demanda foi a supressão do impedimento de uso de recursos } \\
\text { públicos para o ensino religioso nas escolas públicas, especificamente para o pagamento } \\
\text { de professores. Cláusula desse tipo existia na primeira LDB, de } 1961 \text {, mas fora } \\
\text { suprimida em 1971, no auge da ditadura. Semelhante procedimento foi acionado em } \\
\text { 1997, com igual sucesso. Além de mostrar as posições em confronto, o autor levanta } \\
\text { hipóteses a respeito das razões que levaram à rápida mudança de posição dos partidos } \\
\text { políticos. Além do financiamento, o autor focaliza a dimensão ideológica da reforma da } \\
\text { LDB, especialmente a definição do ensino religioso como parte integrante da formação } \\
\text { básica do cidadão. A conclusão do artigo foi que a reforma da LDB reduziu a } \\
\text { autonomia do campo educacional no Brasil, por institucionalizar sua imbricação com o } \\
\text { campo religioso. }\end{array}$ & $\begin{array}{l}\text { LDB, Educação } \\
\text { brasileira, Política } \\
\text { Educacional, Ensino } \\
\text { religioso, } \\
\text { Secularismo. }\end{array}$ \\
\hline 3 & $\begin{array}{l}\text { No final do século XIX, a igreja católica encontrava-se ameaçada dos dois lados do } \\
\text { Atlântico. Na Europa, por conta da afirmação dos Estados nacionais, vê minguar seu } \\
\text { espaço de influência, que será afetado num setor que tradicionalmente dependera de sua } \\
\text { atuação: a educação. No Brasil, o advento da República consolidará na separação da } \\
\text { Igreja e do Estado e na exclusão do ensino religioso das escolas públicas. A reação } \\
\text { antiliberal (ultramontana) da Igreja contará no Brasil com o auxílio de congregações } \\
\text { religiosas para ação evangélica e educacional, sendo analisada aqui iniciativa dos } \\
\text { Salesianos na edificação de uma escola profissionalizante em Cachoeira do Campo, } \\
\text { distrito de Ouro Preto-MG. Destacam-se as intensas relações de caráter político entre } \\
\text { religiosos e poderes públicos no âmbito regional e local. Em 1893, os Salesianos } \\
\text { recebem do Estado terreno e significativa dotação para iniciar as obras do colégio, } \\
\text { seguida de outras dotações, que permitem sua inauguração em } 1896 \text {. De Ouro Preto, os } \\
\text { padres contaram com o Fundo das Crianças Pobres para aplicação no colégio, } \\
\text { comprometendo-se a abrigar órfãos do município, escolhidos pela Câmara. Desta } \\
\text { forma, o Colégio D. Bosco cumpre várias funções, doutrinárias, profissionalizantes e } \\
\text { educacionais, atendendo tanto interesses da igreja quanto do Estado mineiro. }\end{array}$ & $\begin{array}{l}\text { Instrução } \\
\text { Profissionalizante, } \\
\text { Estado e Igreja } \\
\text { Católica, } \\
\text { Estado de Minas } \\
\text { Gerais. }\end{array}$ \\
\hline 4 & $\begin{array}{l}\text { Este trabalho examina implicações e desafios ao ensino de Ciências e Biologia } \\
\text { emergentes da implantação de lei obrigando o ensino religioso na forma confessional } \\
\text { no estado do Rio de Janeiro. Utilizamos como fonte cartas dos leitores de O Globo, } \\
\text { além de outros pronunciamentos da mídia e textos acadêmicos. A polêmica do ensino } \\
\text { religioso nas escolas públicas brasileiras aparece associada a novos elementos, incluindo } \\
\text { pela primeira vez discussões ligadas não apenas a cidadania e liberdade religiosa, mas } \\
\text { também ao confronto entre os pontos de vista criacionista e evolucionista, }\end{array}$ & $\begin{array}{l}\text { Evolução, } \\
\text { Ensino de Ciências, } \\
\text { Ensino de Biologia, } \\
\text { Ensino Religioso, } \\
\text { Criacionismo. }\end{array}$ \\
\hline
\end{tabular}




\begin{tabular}{|c|c|c|}
\hline & $\begin{array}{l}\text { relativamente novo no Brasil, com enorme potencial de crescimento. Este cenário } \\
\text { resulta da formação de novas alianças entre grupos religiosos disputando o espaço } \\
\text { público com defensores da laicidade. Diante disso, reforçamos a importância das } \\
\text { atividades de divulgação científica e de demarcação da natureza da Ciência, sendo } \\
\text { especialmente importantes nesse sentido as contribuições da Filosofia e História da } \\
\text { Ciência. }\end{array}$ & \\
\hline 5 & $\begin{array}{l}\text { A proposta deste artigo é a de abordar a temática do Ensino Religioso sob a perspectiva } \\
\text { do dilema epistemológico, tendo como escopo identificar uma possível contribuição, } \\
\text { que pode ser dada à formação docente por meio da Área de Conhecimento referente às } \\
\text { Ciências da Religião. Nesse sentido, procurou-se traçar um caminho que começa pela } \\
\text { apresentação do dilema epistemológico do Ensino Religioso, sob a ótica da relação } \\
\text { histórica, no Brasil, entre Estado e Religião, destacando as categorias de público e } \\
\text { privado. Feito isso, passa-se então a uma abordagem de modelos teóricos da disciplina, } \\
\text { enquanto categorias de análise, que servem de referência de estudo e compreensão da } \\
\text { temática. Nesse ponto, destacam-se os modelos Catequético, Teológico e das Ciências } \\
\text { da Religião. Ao final desse percurso, procurou-se então estabelecer a relação entre } \\
\text { Modelo das Ciências da Religião, pluralismo religioso e pequenas aproximações à } \\
\text { questão da formação docente; tendo como referência dados que dizem respeito, } \\
\text { sobretudo, à presença do Ensino Religioso em Minas Gerais. }\end{array}$ & $\begin{array}{l}\text { Ensino Religioso, } \\
\text { Dilema } \\
\text { epistemológico, } \\
\text { Ciências da Religião, } \\
\text { Formação docente. }\end{array}$ \\
\hline 6 & $\begin{array}{l}\text { Este trabalho apresenta elementos analíticos que relacionam processos de } \\
\text { regulamentação jurídica e de controle da escola quanto ao Ensino Religioso. A } \\
\text { metodologia está embasada em pesquisa documental e bibliográfica. O arco } \\
\text { cronológico abrange desde o período colonial ate a década de 1930. Mostra-se que } \\
\text { alianças e embates quanto ao Ensino Religioso na historia da educação brasileira foram } \\
\text { nutridos desde os primórdios devido às influências da Igreja Católica e de autoridades } \\
\text { eclesiásticas, assim como de outras instituições e intelectuais defensores de princípios e } \\
\text { valores religiosos. E que durante o Império, bem como nos anos } 1930 \text { da era } \\
\text { republicana, podem ser situados aspectos centrais e que constituíram a base para a } \\
\text { configuração e caracterização das polêmicas e das formas de organização da escola } \\
\text { brasileira quanto ao Ensino Religioso, embasados e orientados pela emergência e } \\
\text { consolidação de controvérsias entre religião e laicidade, sendo o papel do Estado, na } \\
\text { formação cultural e escolarização da população, um dos núcleos centrais do debate. }\end{array}$ & $\begin{array}{l}\text { Ensino } \\
\text { confessional, Escola } \\
\text { laica, República. }\end{array}$ \\
\hline 7 & $\begin{array}{l}\text { O artigo analisa a atuação de Cecília Meireles no combate ao decreto do ensino } \\
\text { religioso nas escolas públicas de } 1931 \text {. Esse tema adquire importância ao percebermos } \\
\text { que alguns estudos que analisaram a trajetória de Cecília Meireles e sua relação com a } \\
\text { educação não aprofundaram os aspectos das críticas à educação religiosa por parte } \\
\text { dessa educadora. O objetivo do artigo é trazer novos elementos do percurso de Cecília } \\
\text { Meireles e seu conflito com as políticas do governo provisório de Getúlio Vargas. Entre } \\
\text { os anos } 1930 \text { e 1933, Meireles escreveu suas críticas aos acontecimentos do período na } \\
\text { Página de Educação do jornal Diário de Notícias. Inicialmente, notamos que essa } \\
\text { educadora assumiu de forma radical o pensamento escolanovista e com ele } \\
\text { fundamentou suas posições em defesa da escola pública. A metodologia utilizada foi a } \\
\text { análise das fontes primárias, a partir de suas relações com os acontecimentos históricos } \\
\text { do período, de uma perspectiva dialética, procurando entender a produção escrita da } \\
\text { educadora em e com o seu tempo. Constatamos no estudo o afastamento e a desilusão } \\
\text { de Cecília Meireles quanto aos rumos do governo Getúlio Vargas. Entretanto, Meireles } \\
\text { manteve seu otimismo na crença em uma escola que atendesse aos interesses da } \\
\text { população brasileira, referenciada no pensamento da Escola Nova e, com isso, teceu } \\
\text { suas críticas ao conservadorismo e à presença da religião no campo educacional } \\
\text { brasileiro. }\end{array}$ & $\begin{array}{l}\text { Cecília Meireles, } \\
\text { Ensino religioso, } \\
\text { Nova escola. }\end{array}$ \\
\hline 8 & $\begin{array}{l}\text { Este artigo aborda o ensino religioso nas escolas públicas, buscando identificar os } \\
\text { posicionamentos de grupos político-ideológicos em torno da questão durante a } \\
\text { tramitação do projeto da Lei de Diretrizes e Bases da Educação Nacional promulgada } \\
\text { em } 20 \text { de dezembro de } 1961 \text {. A análise tomou como fonte o Diário do Congresso } \\
\text { Nacional no período entre } 1948 \text { e } 1962 \text {. Constatou-se que, durante o longo período de } \\
\text { tramitação do projeto na Câmara dos Deputados, diferentes pressões imprimiram suas } \\
\text { marcas na LDB: de um lado, a extensão do dispositivo constitucional sobre o ensino } \\
\text { religioso nas escolas públicas, a fim de atender aos interesses da Igreja Católica, a única } \\
\text { organização manifestamente comprometida com sua oferta; de outro lado, uma aliança } \\
\text { de amplo espectro, mas inorgânica, que, sem condições políticas de defender um } \\
\text { projeto laico para a educação pública, limitou-se a resistir ao avanço do } \\
\text { confessionalismo. Ao fim e ao cabo, nenhum dos dois lados foi capaz de fazer valer }\end{array}$ & $\begin{array}{l}\text { LDB, Educação } \\
\text { brasileira, Política } \\
\text { educacional, Ensino } \\
\text { Religioso, Laicidade. }\end{array}$ \\
\hline
\end{tabular}




\begin{tabular}{|c|c|c|}
\hline & $\begin{array}{l}\text { completamente suas demandas, de modo que a lei promulgada e sancionada resultou } \\
\text { em um produto híbrido, em razão de possível acordo entre os membros da Comissão } \\
\text { de Educação e Cultura da Câmara dos Deputados, pelo menos no que diz respeito à } \\
\text { questão do ensino religioso nas escolas públicas. }\end{array}$ & \\
\hline 9 & $\begin{array}{l}\text { Este trabalho apresenta um levantamento bibliográfico sobre as mudanças sociais no } \\
\text { decorrer histórico do Brasil para que fosse declarado um país laico. Buscou-se } \\
\text { contextualizar essas mudanças que influenciaram o campo educacional tendo como } \\
\text { problema central a postura de um professor de uma escola da rede pública de Sinop em } \\
\text { relação à laicidade na educação atualmente. Numa visão política na busca de uma } \\
\text { educação sem proselitismos religiosos, o estudo tem importância de evidenciar como a } \\
\text { postura do profissional facilita ou não trabalhar eixos atuais da educação. }\end{array}$ & $\begin{array}{l}\text { Educação laica, } \\
\text { proselitismo, ensino } \\
\text { religioso. }\end{array}$ \\
\hline 10 & $\begin{array}{l}\text { Este artigo é resultado da pesquisa qualitativa histórica documental sobre a construção } \\
\text { da disciplina do Ensino Religioso a partir dos livros didáticos. Uma das estratégias para } \\
\text { compreender a formação dos componentes curriculares no espaço da escola, sendo } \\
\text { uma instituição da modernidade que está intimamente relacionada ao projeto da } \\
\text { sociedade burguesa urbano-industrial, é refletir como seus caracteres são construídos. A } \\
\text { escola vem desempenhando a função de formar e conformar os sujeitos individuais e } \\
\text { coletivos aos padrões de racionalização e burocratização dessa sociedade. Embora } \\
\text { outras instituições sociais realizem a mesma tarefa, cabe à escola o papel de transmitir } \\
\text { os saberes legitimados, fundamental para atender às demandas sociais. Os componentes } \\
\text { curriculares colaboram nesta mediação e, dentre outros, é no Ensino Religioso que se } \\
\text { percebe concretizado especialmente pelos livros didáticos, que por meio de seus textos } \\
\text { e exercícios expressam saberes a serem transmitidos. Compreende-se que por meio dos } \\
\text { livros didáticos é possível verificar o desenvolvimento desta disciplina, especialmente } \\
\text { em sua origem quando era denominada aula de religião, e que pretendia consolidar o } \\
\text { projeto de uma religião hegemônica do país, através de seus catecismos como } \\
\text { instrumento de ensino de inúmeras gerações. }\end{array}$ & $\begin{array}{l}\text { Ensino Religioso, } \\
\text { Livro Didático, } \\
\text { Catecismo. }\end{array}$ \\
\hline 11 & $\begin{array}{l}\text { Entendemos que nenhuma sociedade constrói o presente e alicerça o futuro sem } \\
\text { compreender sua cultura e sem conhecer o significado de sua história. O objetivo deste } \\
\text { artigo consiste em apresentar uma metodologia aplicada na sala de aula das primeiras } \\
\text { séries do ensino fundamental, cujo propósito foi despertar a imaginação simbólica dos } \\
\text { alunos através do uso das lendas presentes nos livros didáticos do ensino religioso } \\
\text { ministradas pelos docentes. Os temas estudados têm como base teórica a } \\
\text { fenomenologia da religião, a antropologia e a teoria geral do imaginário. Selecionamos } \\
\text { para nosso estudo como fundamentação metodológica a pesquisa descritiva, de campo } \\
\text { e a abordagem qualitativa para análise dos dados. Ponderamos que a pesquisa descritiva } \\
\text { observa, registra, analisa e correlaciona fatos ou fenômenos sem manipulá-los, ela } \\
\text { procura descobrir, com precisão possível, a frequência com que um fenômeno ocorre, } \\
\text { sua relação e conexão com outros, sua natureza e característica. Nos primeiros } \\
\text { resultados de nossa investigação cientifica foi identificado que as lendas trabalhadas na } \\
\text { sala de aula potencializam o imaginário popular resguardando a identidade cultural de } \\
\text { uma manifestação religiosa. Consideramos que esta metodologia de ensino proposta } \\
\text { pode ser implantada pelos professores do ensino religioso no seu planejamento. }\end{array}$ & $\begin{array}{l}\text { Lendas, Imaginação, } \\
\text { Educação. }\end{array}$ \\
\hline 12 & $\begin{array}{l}\text { Este artigo descreve a experiência com um trabalho interdisciplinar entre as disciplinas } \\
\text { de História, Ensino Religioso e Filosofia, desenvolvida em } 2004 \text {, na Escola Estadual } \\
\text { Agnes Rondon Ribeiro (atualmente municipalizada), localizada na cidade de Santa Fé } \\
\text { do Sul no interior do estado de São Paulo, no que tange à preparação de alunos no final } \\
\text { do Ensino Fundamental II ( } 8^{a} \text { série) e no Ensino Médio }\left(1^{\circ} \text { e } 2^{\circ} \text { ano) para o exercício }\right. \\
\text { da cidadania, a escolha profissional e a reflexão do mundo em que vivem. A análise } \\
\text { desenvolvida neste texto mostrou a importância de um trabalho integrado na escola. A } \\
\text { forma pela qual os professores compactuam certos temas e os trabalham de maneira } \\
\text { interdisciplinar entre o Ensino Fundamental e o Ensino Médio pode ser decisivo na } \\
\text { formação dos alunos. Aqui vimos como esse tipo de trabalho pode ser frutífero para } \\
\text { propiciar o amadurecimento da personalidade dos alunos, constituindo-se em um dos } \\
\text { fundamentos para suas escolhas religiosas e profissionais, bem como vir a favorecer o } \\
\text { exercício de sua cidadania na sociedade brasileira. }\end{array}$ & $\begin{array}{l}\text { Personalidade, } \\
\text { Adolescência, } \\
\text { Cidadania, } \\
\text { Profissão. }\end{array}$ \\
\hline 13 & $\begin{array}{l}\text { Yalorixás são mães de santo do Candomblé; possuem reconhecimento social e força de } \\
\text { mobilização e, ao mesmo tempo, convivem com situações de racismo e intolerância } \\
\text { dentro ou fora de suas comunidades. Neste artigo, procuramos discutir a relação entre } \\
\text { educação escolar e religiosidade a partir da visão de cinco Yalorixás do Candomblé da } \\
\text { Baixada Fluminense. Por meio de entrevistas e observações realizadas entre maio de } \\
2014 \text { e janeiro de } 2015 \text {, em quatro diferentes terreiros dessa região, identificamos como }\end{array}$ & $\begin{array}{l}\text { Candomblé; } \\
\text { Educação pública; } \\
\text { Racismo; Ensino } \\
\text { Religioso. }\end{array}$ \\
\hline
\end{tabular}




\begin{tabular}{|c|c|c|}
\hline & $\begin{array}{l}\text { essas líderes religiosas percebem a intolerância, o racismo e discutem criticamente o } \\
\text { ensino religioso na rede pública do Rio de Janeiro. }\end{array}$ & \\
\hline 14 & $\begin{array}{l}\text { Este trabalho tem por objetivo identificar as relações discursivas e os mecanismos } \\
\text { utilizados pelas fontes - discursos coletados na imprensa e em sítios especializados - na } \\
\text { construção dos pontos de vista apresentados sobre os livros didáticos de ensino } \\
\text { religioso e, em decorrência disso, da relação polêmica construída a partir daí. A } \\
\text { fundamentação teórica deste trabalho assenta-se majoritariamente nos conceitos de } \\
\text { semântica global e interincompreensão constitutiva (MAINGUENEAU, 1997, 2008) e } \\
\text { de heterogeneidade discursiva (AUTHIER-REVUZ, 1990, 1998). O corpus de pesquisa } \\
\text { constituiu-se de quatro textos, três deles publicados em } 2010 \text { e o outro em 2011, sendo } \\
\text { duas reportagens e dois artigos de opinião acerca da temática. A partir das análises, } \\
\text { pudemos verificar a construção de uma relação polêmica entre uma formação discursiva } \\
\text { que contesta o ensino religioso no ensino público brasileiro, sob a justificativa de isso } \\
\text { beneficiar a fé cristã. Por outro lado, outra que apoia a continuidade dessa prática por } \\
\text { considerá-la importante para a formação do educando e, também, como promotora da } \\
\text { diversidade e da igualdade. }\end{array}$ & $\begin{array}{l}\text { Relações } \\
\text { Discursivas, } \\
\text { Semântica Global, } \\
\text { Jornalismo, Material } \\
\text { Pedagógico, } \\
\text { Educação Religiosa. }\end{array}$ \\
\hline 15 & $\begin{array}{l}\text { Esta pesquisa teve como objetivo promover uma reflexão sobre a disciplina de Ensino } \\
\text { Religioso, e sua relação no currículo escolar do Ensino Público, e a realidade das } \\
\text { práticas pedagógicas do ensino religioso na escola da rede pública municipal Lizamara } \\
\text { Aparecida Oliva de Almeida. Os sujeitos da pesquisa foram os professores da disciplina } \\
\text { de ensino religioso. O desenvolvimento do estudo iniciou-se com uma análise } \\
\text { bibliográfica, com questionário semiaberto e as observações em sala de aula, utilizando- } \\
\text { se da pesquisa qualitativa. O conhecimento na área da Ciência da Religião para a } \\
\text { docência dessa disciplina é responsável por inserir no meio escolar o pluralismo, o não } \\
\text { preconceito, e o respeito. }\end{array}$ & $\begin{array}{l}\text { Ensino religioso; } \\
\text { formação de } \\
\text { docentes; escola } \\
\text { pública. }\end{array}$ \\
\hline 16 & $\begin{array}{l}\text { Este artigo analisa a proposta da disciplina ensino religioso na Base Nacional Curricular } \\
\text { Comum para o Ensino Fundamental como elemento de política pública, segundo dois } \\
\text { pontos de vista: o do processo de sua produção e o do produto. A produção dessa } \\
\text { política foi analisada a partir dos agentes que a propuseram, particularmente da ONG } \\
\text { Fórum Nacional Permanente para o Ensino Religioso - (FONAPER), um grupo social } \\
\text { de interesse constituído pelo segmento católico do campo religioso. O produto foi } \\
\text { analisado a partir do cotejo da proposta curricular com a concepção da escola laica } \\
\text { enunciada no Observatório da Laicidade na Educação (OLE). O artigo conclui que não } \\
\text { há justificativa pedagógica legítima para o ensino religioso no currículo da escola } \\
\text { pública. }\end{array}$ & $\begin{array}{l}\text { Educação pública, } \\
\text { Educação religiosa, } \\
\text { Política educacional, } \\
\text { Educação laica. }\end{array}$ \\
\hline 17 & $\begin{array}{l}\text { Pesquisa realizada entre } 2010 \text { e } 2012 \text { constatou a existência de expressões religiosas em } \\
60,87 \% \text { das escolas públicas de ensino médio do Distrito Federal, abrangendo } \\
\text { expressões religiosas materializadas na forma de gravuras, estátuas, grafites, rabiscos e } \\
\text { cartazes. Expressões religiosas de autoria dos atores institucionais: professores, alunos, } \\
\text { funcionários técnico-administrativos e gestores escolares. O método utilizado na } \\
\text { pesquisa foi o indutivo com abordagem qualitativa. Adotaram-se três procedimentos: } \\
\text { fotografar as representações; entrevistar gestores; realizar grupo de discussão com } \\
\text { alunos. O artigo demonstra que o fenômeno insere-se no conflito estrutural do setor } \\
\text { educacional brasileiro: ensino religioso versus laicidade e discute teoricamente se o } \\
\text { fenômeno consiste em representações sociais ou ideologia. }\end{array}$ & $\begin{array}{l}\text { Representações } \\
\text { Sociais, Ideologia, } \\
\text { Religião, Ensino } \\
\text { Médio, Escola } \\
\text { Pública. }\end{array}$ \\
\hline 18 & $\begin{array}{l}\text { A criação do Sistema Nacional de Educação no Brasil tem sido justificada por diversos } \\
\text { elementos, entre os quais não aparece a laicidade da educação pública. Para o autor, tal } \\
\text { omissão expressa a insuficiente compreensão do Estado republicano e de suas políticas, } \\
\text { em especial as políticas educacionais. Esse conveniente (conivente?) silêncio propicia a } \\
\text { situação atual da disciplina Ensino Religioso nas escolas públicas, marcada pela anomia } \\
\text { jurídica e pela folia pedagógica. Ambas as "patologias" prosperam no aparato } \\
\text { educacional brasileiro, fragmentado em múltiplos sistemas, o que abre espaço para a } \\
\text { luta pela hegemonia religiosa no campo educacional, privando a escola pública de uma } \\
\text { condição essencial da prática republicana - a liberdade de pensamento e de crença, uma } \\
\text { e outra propiciadas pela laicidade do Estado. }\end{array}$ & $\begin{array}{l}\text { Laicidade, Escola } \\
\text { pública, Políticas } \\
\text { educacionais, } \\
\text { Educação brasileira. }\end{array}$ \\
\hline 19 & $\begin{array}{l}\text { O objetivo deste artigo é discutir a atual configuração legal do Ensino Religioso no } \\
\text { Estado do Rio de Janeiro, que se regulamenta pela Lei Estadual de no } 3.459 \text {, de } 14 \text { de } \\
\text { setembro de } 2000 \text {. Entende-se aqui que esta legislação fluminense não atende as } \\
\text { premissas expressas pela Lei Federal de n } 9.475 \text {, de 1997. Para se elucidar tal discussão, } \\
\text { recorre-se, num primeiro momento, a uma metodologia de discussão teórica de } \\
\text { determinados conceitos, entre eles os de "laicização", "laicidade", "confessionalismo", } \\
\text { "resistência ativa", "estrutura de plausibilidade" e "proselitismo" para tentar perceber }\end{array}$ & $\begin{array}{l}\text { Legislação } \\
\text { Educacional, Ensino } \\
\text { Religioso, Ensino } \\
\text { Religioso no estado } \\
\text { do Rio de Janeiro. }\end{array}$ \\
\hline
\end{tabular}




\begin{tabular}{|c|c|c|}
\hline & $\begin{array}{l}\text { como esses conceitos podem contribuir para se perceber a dinâmica do ER. Já num } \\
\text { segundo momento, volta-se para a compreensão das prerrogativas legais e educacionais } \\
\text { que envolvem o ER em sua atual configuração na Escola pública brasileira e, em } \\
\text { especial, no Estado do Rio de Janeiro. E, em meio a esta perspectiva, sob a lente da } \\
\text { análise histórica almeja-se perceber os meandros percorridos pelo ER nesse Estado } \\
\text { enquanto uma política educacional que, atualmente, possibilita ao proselitismo se fazer } \\
\text { presente no ambiente das escolas estaduais fluminenses. }\end{array}$ & \\
\hline 20 & $\begin{array}{l}\text { Este artigo apresenta abordagens teóricas que discutem as categorias descritivas esfera } \\
\text { pública e esfera privada, as noções de laico/laicidade, o paradigma da secularização e o } \\
\text { secular. Objetivamos contribuir para uma analítica sobre o uso desses termos no } \\
\text { tratamento de questões que envolvem a relação entre Estado e religião. Após a } \\
\text { delimitação desse quadro teórico pretende-se subsidiar epistemologicamente o debate } \\
\text { sobre ensino religioso nas escolas públicas do Estado brasileiro. Considerando a relação } \\
\text { com diferentes lugares sociais e tempos históricos, estamos interessados nos sentidos } \\
\text { dessas noções produzidos histórica, política e culturalmente. Para além de indicar a } \\
\text { incompatibilidade do fato religioso na esfera pública ou apontar sua centralidade para a } \\
\text { sociedade, propomos pensar a relação entre Estado e religião na modernidade marcada } \\
\text { pela reinvenção de ambas. Nesse sentido, entendemos que o exercício de repensar } \\
\text { categorias descritivas e sistemas de classificações seja positivo para a elaboração de um } \\
\text { tipo de ensino religioso que contemple a complexidade de nossa realidade social. }\end{array}$ & $\begin{array}{l}\text { Religião, Estado, } \\
\text { Esfera } \\
\text { pública/privada. } \\
\text { Secularização, } \\
\text { Laicidade. }\end{array}$ \\
\hline 21 & $\begin{array}{l}\text { Esta pesquisa realizada em escolas públicas estaduais e municipais de Recife em } \\
\text { Pernambuco por meio de projeto de iniciação científica que contou com o apoio da } \\
\text { UFPE e do CNPq teve como objetivo, analisar no currículo da disciplina de Ensino } \\
\text { Religioso (ER), o lugar que mulheres, especialmente as com orientação sexual } \\
\text { marginalizada como lésbicas, bissexuais e transexuais, ocupam. Para tal, trabalhamos } \\
\text { com a metodologia da Análise de Discurso e com a Teoria do Discurso, procurando } \\
\text { primeiro, identificar as principais ideologias que cercavam e envolviam o tema, para em } \\
\text { seguida, localizar o discurso hegemônico ou os discursos hegemônicos que se } \\
\text { afirmavam ao redor dele. Sendo assim, chegou-se à conclusão que abordagens sobre } \\
\text { religião, gênero e diversidade sexual, que são expressas no cotidiano das salas de aula, } \\
\text { não são, no entanto, levantadas no componente disciplinar examinado devido à } \\
\text { ausência de um currículo que possa auxiliar docentes por meio de atividades propostas } \\
\text { e conteúdos pragmáticos que estimulem o surgimento de pontos a serem considerados, } \\
\text { negociados e correlacionados às temáticas em questão. Sendo assim, as dificuldades em } \\
\text { se dialogar acerca da orientação sexual e homossexualidade de modo geral, e } \\
\text { especificamente, no caso feminino, são grandes na disciplina de ER nas escolas } \\
\text { pesquisadas. }\end{array}$ & $\begin{array}{l}\text { Educação, Ensino } \\
\text { Religioso, Gênero, } \\
\text { Orientação Sexual, } \\
\text { Currículo, Ensino } \\
\text { Religioso Gênero e } \\
\text { Sexualidade. }\end{array}$ \\
\hline
\end{tabular}

Fonte: Elaboração própria a partir do Portal de Periódicos da CAPES.

Submetido: $14 / 03 / 2020$

Aprovado: $20 / 08 / 2020$ 